\title{
Multispectral Reflectance of Cotton Related to Plant Growth, Soil Water and Texture, and Site Elevation
}

\author{
Hong Li, Robert J. Lascano,* Edward M. Barnes, Jill Booker, L. Ted Wilson, \\ Kevin F. Bronson, and Eduardo Segarra
}

\begin{abstract}
Radiometric data can be useful to determine the impact of field leterogeneity, irrigation, and fertilization on plant water and $\mathrm{N}$ use. A 2-yr (1998-1999) study was conducted on the South Texas High Pluins to investigate cotton (Gossypium hirsutum L.) spectral and agronomic responses to irrigation and $\mathrm{N}$ fertilization and to determine the simple and cross correlation among cotton reflectance, plant growth, $\mathbf{N}$ uptake, lint yield, site elevation (SE), and soil water and texture. The treatments were irrigution at 50 and $75 \%$ of calculated cotton evapotranspiration (ET) and $N$ rates of 0,90 , and $135 \mathrm{~kg} \mathrm{ha}^{-1}$ arranged in an incomplete block of size-2 design. Plant and soil spectral properties were investigated within a wavelength of 447 to $1752 \mathrm{~nm}$. Near-infrared (NIR) reflectance was positively correluted with plant biomass and $\mathrm{N}$ uptake. Reflectance in the red and midinfrared band increased with SE. The mixed-model analysis showed that cotton NIR reflectunce, normalized difference vegetative index (NDVI), soil water, $\mathrm{N}$ uptake, and lint yield were significantly affected by irrigation $(P<0.0012)$. The N treutment had no effect on spectral parameters, and interaction between irrigation and $N$ fertilizer was significant on NIR reflectunce $(P<0.0027)$. All spectral and agronomic parameters measured were associated with SE. The red und NIR reflectance and NDVI were cross-correlated with soil water, sand, clny, and SE across a distance of 60 to $80 \mathrm{~m}$. Characterization of plant and soil reflectance and their spatial structure can be the basis for variable $N$ application on heterogencous fields to increase $\mathbf{N}$ use efficiency.
\end{abstract}

$\mathrm{W}$ ATER AND N aVAILABILITY are recognized as limiting factors for cotton production in the semiarid southern High Plains of Texas where most agricultural fields are characterized by surface elevation undulation. With the introduction of site-specific management practices, there is a need for variable water and $\mathrm{N}$ application related to field topographic features such as site elevation (SE) and slope length. In addition, remotely sensed data could be the basis for water, $\mathrm{N}$, and crop management (Jackson, 1984; Blackmer et al., 1996). For example, soil-plant reflectance data and spectral vegetation indices have been used to characterize soil conditions and plant development of several crops (Ahlrichs and Bauer, 1983; Bowman, 1989; Richardson et al., 1992; Wiegand et al., 1994; Barnes et al., 1997; Mass, 1998; Sembiring et al., 1998); detect cotton relative leaf water content, total water potential, and lint yield (Bowman, 1989; Wiegand et al., 1994; Plant et al., 2000); make day-

H. Li and K.F. Bronson, Texas A\&M Univ., Rt. 3, Box 219, Lubbock, TX 79403; R.J. Lascano and J. Booker, Texas A\&M Univ., USDAARS, 3810 4th Street, Lubbock, TX 79415; E.M. Barnes, USDAARS, U.S. Water Conserv. Lab., 4331 E. Broodway, Phoenix, AZ; L.T. Wilson, Texas A\&M Univ., 1509 Aggie Drive, Beaumont, TX 77713; and E. Segarra, Dep. of Agric. and Appl. Econ., Texas Tech Univ., Lubbock, TX 79409. H. Li, current address: Dep. of Soil Sci., North Carolina State Univ., Raleigh, NC 27695. Received 16 Oct. 2000. *Corresponding author (r-lascano@tamu.edu).

Published in Agron. J. 93:1327-1337 (2001). to-day irrigation and fertilization management decisions (Jackson, 1984); and for in-season $\mathrm{N}$ management (Stone et al., 1996).

Spectral leaf reflectance as a function of wavelength between 400 and $2500 \mathrm{~nm}$ was used to determine soybean [Glycine max (L.) Merr.] (Kollenkark et al., 1982) and cotton (Bowman, 1989) plant water status as well as corn leaf water stress (Bausch, 1993) and $\mathrm{N}$ deficiency (Blackmer et al., 1996). Soybean spectral reflectance at 760 to $840 \mathrm{~nm}$ was correlated with leaf area index (LAI), fresh and dry biomass, percent soil cover, and grain yield (Kollenkark et al., 1982). Spectral reflectance at 810 and $1665 \mathrm{~nm}$ was correlated with leaf relative water content and total water potential (Bowman, 1989). The reflected wavelengths most sensitive to detecting $\mathrm{N}$ deficiencies in a corn canopy were 550 and $710 \mathrm{~nm}$ based on their correlation with grain yield (Walburg et al., 1982; Blackmer et al., 1996). Both water and $\mathrm{N}$ stresses altered plant reflectance and lowered normalized difference vegetative index (NDVI) values (Plant et al., 2000). Cotton lint yield was significantly correlated with soil water and sand contents ( $\mathrm{Li}$ et al., 2001a), red and near-infrared (NIR) reflectance, and NDVI (Wiegand et al., 1994; Plant et al., 2000; Li et al., 2001b), and temporal patterns of cotton reflectance were related to plant growth at different stages (Plant et al., 2000; Li et al., 2001b). These results suggest that it may be possible to use spatial and temporal patterns of plant reflectance and spectral index for in-season water and $\mathrm{N}$ management. However, the difficulty is that the spectral signal for a given crop is complex because it is simultaneously affected by many soil and plant variables.

Soil texture, moisture, plant cover, and landscape surface roughness could affect soil and plant reflectance in the visible and NIR wavelength regions (Kollenkark et al., 1982; Jackson, 1984, 1987; Begue, 1993; Asner, 1998). Plant reflectance, NIR/red reflectance ratio, and the NDVI were different with stress events, sun angles, cultivars, and irrigation and fertilization treatments (Daughtry et al., 1992; Wiegand et al., 1994; Begue, 1993; Blackmer et al., 1996; Stone et al., 1996). Stress events, such as drought, reduced spectral estimates of absorbed radiation and NDVI in corn and soybean canopies (Daughtry et al., 1992). Weather variability also affected canopy spectral characteristics because NDVI traits measured on grassland had a negative and nonlinear relationship with annual precipitation (Paruelo and Lauenroth, 1998). Further, landscape factors also caused variation of crop reflectance signal (Asner, 1998; Pachepsky and Ritchie,

Abloreviations: ET, evapotranspiration; LAI, leaf area index; MIR, midinfrared; NDVI, normalized difference vegetative index; NIR, near infrared; PFB, plant fresh biomass; PWC, plant water content; $\mathrm{SE}$, site elevation; SWC, soil water content. 
1998). There is experimental evidence that field heterogeneity, such as SE, may also affect water and $\mathrm{N}$ distribution patterns and that dynamic soil and crop variables should then be measured as a function of space and time (van Es et al., 1989; van Es and van Es, 1993; Lascano et al., 1999; Cassel et al., 2000; Li et al., 2001a).

Understanding the relationship among crop reflectance, water and $\mathrm{N}$ inputs, and field heterogeneity would be useful for further evaluation of remote sensing as a tool for irrigation and fertilization monitoring. For this study, we hypothesized that water and $\mathrm{N}$ supply and field heterogeneity would affect cotton spectral reflectance and agronomic variables. The objectives of the study were to (i) assess cotton-soil reflectance related to plant biomass, plant water content (PWC), $N$ uptake, lint yield, and soil properties with different rates of irrigation and $\mathrm{N}$ fertilizer; (ii) determine the effects of the treatments on spectral and agronomic response variables; (iii) develop NDVI maps; and (iv) determine the linear correlation and cross correlation between spectral reflectance and vegetation index, agronomic parameters, soil water and texture, and topography for in-season $\mathrm{N}$ management.

\section{MATERIALS AND METHODS}

\section{Site Characteristics and Experimental Setup}

The experimental site is located in a center pivot irrigated field ( $45 \mathrm{ha})$ at the Lamesa Agricultural Research Farm $\left(32^{\circ} 46^{\prime} \mathrm{N}, 101^{\circ} 56^{\prime} \mathrm{W}\right)$ of Texas A\&M University on the southern High Plains of Texas. In spring 1998, the USDA-NRCS surveyed the altitude across the entire field using a Trimble Survey Grade GPS Model 4700 Dual Channel RTK system (Trimble, Sunnyvale, CA). Altitude at the site declines from west to east and gradually downward from south toward the center, and then it gently rolls upward to the north. The surface soil is structureless, brown (7.5YR 5/4; $4 / 4$, moist), well drained, and highly erodible. The soil is classified as an Amarillo sandy loam (mixed, superactive, thermic Aridic Paleustalf). The surface soil layer is underlaid by soft, pink, caliche material, and the depth to caliche varied between 0.65 and $1.45 \mathrm{~m}$. The surface soil $(0-0.3 \mathrm{~m})$ contained on average $810 \mathrm{~g} \mathrm{~kg}^{-1}$ sand and $140 \mathrm{~g} \mathrm{~kg}^{-1}$ clay. Additional information about this soil is given in $\mathrm{Li}$ et al. (2001a).

The 2-yr field study started in May 1998. The experimental area was $32 \mathrm{~m}$ wide and $700 \mathrm{~m}$ long across an altitude between 890.8 and $894.6 \mathrm{~m}$ above sea level. The experimental treatments consisted of irrigation at $50 \%$ and $75 \%$ of cotton potential evapotranspiration (ET) and $\mathrm{N}$ fertilization at rates of 0 , 90 , and $135 \mathrm{~kg} \mathrm{ha}^{-1}$ arranged in an incomplete block of size-2 design and selected to minimize effects of field heterogeneity on outcome of treatments (van Es et al., 1989; van Es and van Es, 1993). There were four replicates for the $\mathrm{N}$ treatment reference (control) and $\mathrm{N}$ at a rate of $135 \mathrm{~kg} \mathrm{ha}^{-1}$ and five replicates for $\mathrm{N}$ at a rate of $90 \mathrm{~kg} \mathrm{ha}^{-1}$. Plot size was twelve 1 - $\mathrm{m}$ rows wide and $50 \mathrm{~m}$ long. Cotton ('Roundup Ready 2326') was seeded at a rate of $16.8 \mathrm{~kg} \mathrm{ha}^{-1}$ in early May each year. Fertilizer $\mathrm{N}$ \{urea $\left[\left(\mathrm{NH}_{2}\right)_{2} \mathrm{CO}\right], 32-0-0$ ) was fractionally applied into soils on rows by a chisel at emergence at a rate of $45 \mathrm{~kg} \mathrm{ha}^{-1}$; at bloom (beginning of July) for the $90 \mathrm{~kg} \mathrm{ha}^{-1}$ rate; and at emergence, bloom, and first square stage (midJuly), respectively, for the $135 \mathrm{~kg} \mathrm{ha}^{-1}$ rate. In-season insect and weed controls were applied according to regional recommendations.
Rainfall was $91 \mathrm{~mm}$ during the growing season in 1998, and in 1999, precipitation was $130 \mathrm{~mm}$ in June and dry the remaining period. Irrigation was applied using a LEPA (Low Energy Precision Application) irrigation system (Lyle and Bordovsky, 1981), and irrigation rates varied between 5.1 and 10.1 (50\% ET) and 7.6 and 15.2 (75\% ET) mm every $3 \mathrm{~d}$, depending on rain amounts and plant requirements at different growth stages. Total irrigation applied was 215 and 323 $\mathrm{mm}$ in 1998 and 190 and $285 \mathrm{~mm}$ in 1999 for the 50 and $75 \%$ $\mathrm{ET}$, respectively.

\section{Multispectral Reflectance and Agronomic Measurements}

Multispectral plant/soil reflectance across the wavelength between 447 and $1752 \mathrm{~nm}$ was measured using a portable MSR16 ( 8 up sensors and 8 down sensors) radiometer (CropScan, Rochester, MN). Measurement distance was $2 \mathrm{~m}$ from sensors (looking straight down) to crop canopy top. With a $31.1^{\circ}$ field of view, the sensor viewed a $1.0-\mathrm{m}$-diam. ground area. On each main plot, plant and soil composite reflectance was measured on harvest rows from four areas: Two were $25 \mathrm{~m}$ apart on Row 6 and the other two also $25 \mathrm{~m}$ apart on Row 7. To maintain the integrity of the spectral measurement areas, plants were not sampled from these two rows. Reflectance was measured twice per week within a 15 to $30^{\circ}$ solar zenith angle throughout the growing season. There were 16 to 20 readings per $\mathrm{N}$ treatment, totaling 104 readings at each measurement event. The sensor output consisted of reflectance in the visible, NIR, and midinfrared (MIR) bands at the center wavelength of $460,559,660,661,710,810,830$, and $1650 \mathrm{~nm}$, respectively.

A 0.5 - by $0.5-\mathrm{m}$ Spectralon panel (Labsphere, Orth Sutton, NH) sintered with polytetrafluoroethylene powder (a very bright reflector), with stable and known reflectance factors (typically between 98.6-99.1\%), was used as a reference reflectance standard surface to calibrate the field reflectance measurements. This calibration was because field measurements of reflectance factors generally involve the measurements of radiance from a relerence panel or a target with the radiometer (Jackson et al., 1987, 1992). In addition, a dry soil reference was measured on a 0.6 - by $0.5-\mathrm{m}$ soil tray (fairly constant reflectance with time) to further verify the calibration, as indicated by Jackson et al. (1987), to account for any drift in the calibration factors and any unexpected changes due to equipment problems that could occur during the season. Spectralon and soil tray readings were taken twice simultaneously at the beginning and the end of each field reflectance measurement event, as suggested by Jackson et al. (1987).

Leaf area index was simultaneously measured with a LAI2000 Plant Canopy Analyzer (LI-COR, Lincoln, NE) at the reflectance measurement positions using the method of Hicks and Lascano (1995). Monthly soil water content (SWC) was measured in $0.3-\mathrm{m}$ increments to a $1.8-\mathrm{m}$ depth using a neutron probe (Model 503 Hydroprobe, CPN Corp., Martinez, CA). Neutron readings were field-calibrated with gravimetric SWC measured at the same soil depth from samples taken three times during the growing season. In addition, monthly surface $(0-0.06 \mathrm{~m})$ SWC was measured at reflectance measurement sites in 1999 with a frequency-domain sensor (ThetaProbe, Delta-T Devices Ltd., Cambridge, England) using the method of Lascano et al. (1999). Site elevation was measured using a SL 2001/3001 L-Band Receiver (Satloc, Scottsdale, AZ), which was calibrated with USDA-NRCS measurements.

In each plot, 16 to 32 plants were sampled from four 5-by 25- $\mathrm{m}$ areas, beside reflectance measurement locations, on a 10 - $d$ interval from early June to harvest. Root length and fresh 
and dry matter of roots, leaves, stems, bolls, and seeds were measured. Plant samples were dried at $70^{\circ} \mathrm{C}$ until constant weight and ground to $0.5 \mathrm{~mm}$. Total plant $\mathrm{N}$ was determined using a LECO FP-528 Analyzer (Leco Corp., St. Joseph, MI). Soil was sampled on the row within $0.5 \mathrm{~m}$ of each neutron access tube to a depth of $1.8 \mathrm{~m}$ in $0.3-\mathrm{m}$ increment at emergence, bloom, and harvest. Soil samples were air-dried and sieved to $2 \mathrm{~mm}$. Soil texture $(n=52$ per ET) was measured using the hydrometer method (Gee and Bauder, 1986), with soils sampled in July 1998. The $0.1 \mathrm{M} \mathrm{KCl}$ extractable $\mathrm{NO}_{3}-\mathrm{N}$ (Technicon Ind. Syst., 1986) was measured using a Technicon Auto-Analyzer II C (Technicon Instruments Corp., Tarrytown, NY). Cotton lint was hand-harvested from four 1- by 4-m areas at reflectance measurement locations in early October of each year.

\section{Reflectance Discrimination and Calculations}

The spectral radiometer readings were calibrated with a reflectance correction factor, which was calculated by applying the dark millivolt readings at $25^{\circ} \mathrm{C}$, temperature sensitivity constants, up-facing sensor cosine parameters, and sun angle values (CropScan). Then, the converted spectral reflectance was expressed as percentage of reflectance, a ratio of output in millivolt of down and up sensors. This was multiplied by a correction factor (a ratio of the known Spectralon reflectance factors to Spectralon readings) to obtain corrected field reflectance values. Soil reflectance was discriminated in the red band between 648 and $674 \mathrm{~nm}$, and plant reflectance was discriminated in the NIR band between 797 and $829 \mathrm{~nm}$.

Total $\mathrm{N}$ uptake was calculated by multiplying total $\mathrm{N}$ content by plant dry matter. Plant water content was determined by difference between fresh and dry biomass. The SWC was obtained by converting neutron probe readings using fieldspecific calibration equations. The ratio vegetative index was expressed as NIR/red reflectance (Jackson, 1984; Sembiring et al., 1998). The NDVI was determined by the ratio of differencing and combining reflectance measured in NIR and red bands (RED) as described by Jackson (1984), Sembiring et al. (1998), and Plant et al. (2000):

$$
\mathrm{NDVI}=(\mathrm{NIR}-\mathrm{RED}) /(\mathrm{NIR}+\mathrm{RED})
$$

The spatial correlation between two variables $x$ (soil texture or SE) and $y$ (cotton reflectance, NDVI, or lint yield) was determined with the cross correlation covariance $\left[\mathbf{C}_{\mathrm{xy}}(\mathbf{h})\right]$ and the cross covariance function $\left[\gamma_{x y}(h)\right]$, as described by Cassel et al. (2000) as follows:

$$
\begin{aligned}
C_{x y}(\mathbf{h}) & =\frac{1}{n(\mathbf{h})} \sum_{\mathbf{i}=1}^{n-h}\left(x_{i+h}-\bar{x}\right)\left(y_{i}-\bar{y}\right) \\
\gamma_{x y}(\mathbf{h}) & =\frac{C_{x y}(\mathbf{h})}{\sigma_{x} \sigma_{y}}
\end{aligned}
$$

where $\mathbf{n}(\mathbf{h})$ in Eq. [2] is the number of pairs of sample points at distance $\mathbf{h}$ apart, $y_{1}$ is the $y$ value at point $\mathbf{i}, x_{\mathrm{i}+\mathrm{h}}$ is the $x$ value at point $\mathbf{i}+\mathbf{h}, \mathbf{h}$ is the lag or the distance between measurements, and $\hat{f}$ and $y$ are the mean of all measurements of $x$ and $y$, respectively (Cassel et al., 2000). In Eq. [3], $\sigma_{x}$ and $\sigma_{y}$ are the standard deviations of $x$ and $y$, respectively.

\section{Data Statistics and Mapping}

Regression analysis of relationships between spectral and agronomic variables and SE were evaluated using the General Linear Models procedure (SAS Inst., 1990). The effects of irrigation and $\mathrm{N}$ fertilizer on multispectral cotton reflectance, SWC, PWC, total N uptake, and cotton lint yield were tested using the PROCMIXED model procedure (Little et al., 1996). The cross correlation covariance and cross covariance function of the reflectance, lint yield, soil texture, and topography were determined using the AutoRegressive Integrated Moving Average (ARIMA) procedure (SAS Inst., 1993). Cotton NDVI maps were generated using data measured in a 2 - by $6-\mathrm{m}$ grid across the plots at plant maturity in August each year using MapInfo 6.0 (MapInfo Corp., Troy, NY).

\section{RESULTS}

\section{Temporal Patterns of Plant Reflectance, Normalized Difference Vegetative Index, Nitrogen Uptake, and Biomass}

The spectral curves show the soil, water, and plant reflectance (monthly mean) as a function of wavelength $(\lambda)$ and crop development (Fig. 1), measured in the $75 \%$ ET plots. The reflectance data measured in the $50 \%$ ET plots showed similar patterns (results not shown). As $\mathrm{N}$ treatments had no effect on reflectance data (Table 1), the means of all $\mathrm{N}$ treatments were plotted in Fig. 1. Sensor outputs are typically in the green, red, NIR, and MIR portions at center wavelength of $460,559,661$, 810 , and $1650 \mathrm{~nm}$, respectively (Fig. 1). In June, red (637-674 nm) reflectance was higher (Fig. 1a), which corresponded to a higher percentage of exposed soil sur-
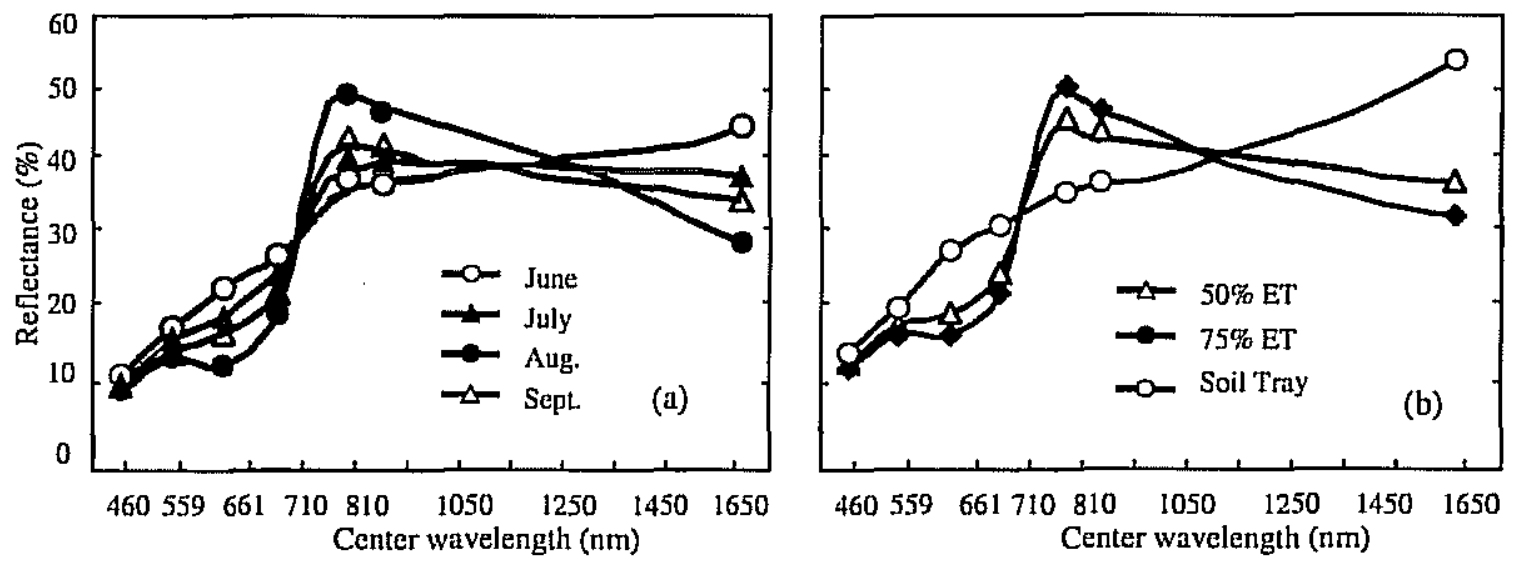

Fig. 1. (a) Mean monthly (average of all $\mathrm{N}$ treatments) soil and cotton multispectrum during the growing season at the $75 \%$ evapotranspiration (ET) and (b) comparison of monthly average surface reflectunce of tray dry soil reference and irrigated cotton, measured in August 1998 . 
Table 1. Fixed effects of the trentments on red and near infrared (NIR) reflectance, normalized difference vegetative index (NDVI), total $N$ uptake, and cotton lint yield. Spectral reflectance was measured 17 Aug. 1998 and 24 Aug. 1999 (when maximum NDVI values were determined).

\begin{tabular}{|c|c|c|c|c|c|c|c|c|c|c|}
\hline \multirow[b]{2}{*}{ Sources } & \multicolumn{2}{|c|}{ Red $(648-674 \mathrm{~nm})$} & \multicolumn{2}{|c|}{ NIR (797-829 nm) } & \multicolumn{2}{|c|}{ NDVI } & \multicolumn{2}{|c|}{ N uptuke } & \multicolumn{2}{|c|}{ Lint yicld } \\
\hline & $\boldsymbol{F}$ & $P$ & $F$ & $P$ & $\boldsymbol{F}$ & $\boldsymbol{P}$ & $F$ & $P$ & $F$ & $\boldsymbol{P}$ \\
\hline \multicolumn{11}{|c|}{1998} \\
\hline $\begin{array}{l}\text { Irrigation (I) } \\
\text { Nitrogen (N) } \\
I \times N\end{array}$ & $\begin{array}{r}24.1 \\
0.41 \\
1.63\end{array}$ & $\begin{array}{l}0.0031 \\
0.6836 \\
0.2020\end{array}$ & $\begin{array}{c}24.8 \\
2.54 \\
4.37\end{array}$ & $\begin{array}{l}0.0026 \\
0.0847 \\
0.0152\end{array}$ & $\begin{array}{c}29.9 \\
0.94 \\
2.39\end{array}$ & $\begin{array}{l}0.0020 \\
0.4404 \\
0.0974\end{array}$ & $\begin{array}{c}15.7 \\
0.3 \\
1.55\end{array}$ & $\begin{array}{l}0.0167 \\
0.7494 \\
0.2178\end{array}$ & $\begin{array}{c}66.1 \\
0.72 \\
0.39\end{array}$ & $\begin{array}{l}0.0012 \\
0.5225 \\
0.6780\end{array}$ \\
\hline \multicolumn{11}{|c|}{1999} \\
\hline $\begin{array}{l}\text { Irrigation (I) } \\
\text { Nitrogen (N) } \\
I \times N\end{array}$ & $\begin{array}{c}25.3 \\
1.85 \\
4.32\end{array}$ & $\begin{array}{l}0.0023 \\
0.2346 \\
0.0163\end{array}$ & $\begin{array}{c}30.5 \\
2.55 \\
4.77\end{array}$ & $\begin{array}{l}0.0024 \\
0.0832 \\
0.0106\end{array}$ & $\begin{array}{c}18.3 \\
2.41 \\
33.5\end{array}$ & $\begin{array}{l}0.0057 \\
0.1609 \\
0.0001\end{array}$ & $\begin{array}{l}0.92 \\
1.19 \\
1.82\end{array}$ & $\begin{array}{l}0.3925 \\
0.3678 \\
0.2416\end{array}$ & $\begin{array}{c}39.2 \\
6.99 \\
2.26\end{array}$ & $\begin{array}{l}0.0039 \\
0.0281 \\
0.1107\end{array}$ \\
\hline
\end{tabular}

face at the early vegetative stage. As cotton plants grew, red radiance decreased and reflected NIR (797-829 nm) increased quickly from June to August (Fig. 1a). The peak of NIR reflectance was measured in mid-August at plant maturity. As a result of a decrease in LAI (from 2.5 to 1.8 ) near the open-boll growth stage in September, the red increased, and reflected NIR decreased simultaneously (Fig. 1a).

The spectral curves also showed the mean monthly reflectance as a function of irrigation level. The dry soil in the tray reflected highly in the red and increased in the MIR band between 1523 to $1752 \mathrm{~nm}$ (Fig. 1b). The plant absorbed blue and red energy more than green and more strongly reflected NIR energy compared with the dry soil. Compared with the $50 \%$ ET, there was a relatively higher absorption of blue $(447-476 \mathrm{~nm})$, red, and MIR energy and a higher reflection of green (546$571 \mathrm{~nm}$ ) and NIR energy on the $75 \%$ ET plots (Fig. 1b). In the MIR band, the reflectance is related to PWC. Higher NIR and lower red and MIR reflectance with the $75 \%$ ET indicated more vigorous plant growth (mean LAI values of 2.4 vs. 2.0 ) compared with the $50 \%$ ET (Fig. 1b).

The NIR and red reflectance-based NDVI, calculated with Eq. [1], showed a temporal pattern comparable to that of LAI (Fig. 2). Because there was no effect of $N$ on NIR and NDVI (Table 1), data plotted in Fig. 2 were the mean of all $\mathrm{N}$ treatments. The LAI varied between 0.1 and 2.7 during the two growing seasons. In 1998, the maximum average NDVI $(n=52)$ was 0.69 (range of

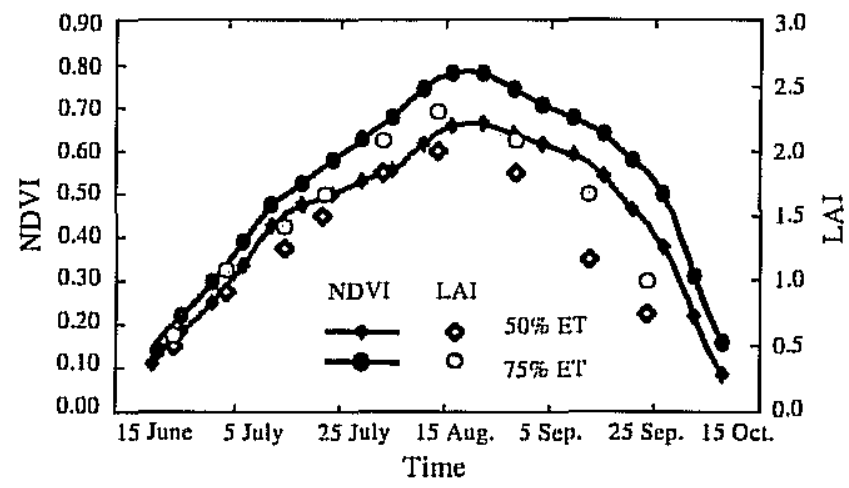

Fig. 2. Temporal patterns of normalized difference vegetative index (NDVI) and leaf ureu index (LAI) as a function of irrigation level, measured in 1998. Data were mean of $\mathbf{N}$ treatments because $\mathrm{N}$ fertilizer had no effect on NDVI and LAI. ET, evapotranspiration.
$0.54-0.82$ ) and 0.76 (range of $0.57-0.83$ ) at the 50 and $75 \%$ ET, respectively, determined on 17 August. Both NDVI and LAI (determined in 1998) increased proportionally with increasing irrigation level (Fig. 2). The peak of NDVI curve was situated towards the end of August. High NDVI was a result of an increase in the NIR band and a decrease in the red band. The NDVI was low at early vegetative growth stage and harvest because the composite reflectance was high in the red band due to less plant ground cover.

The NDVI and N uptake followed an S-shaped growing pattern from vegetative stage to open boll (towards end of August) and then declined (Fig. $3 a$ and $3 b$ ). Because there was no difference in agronomic parameters between $\mathrm{N}$ rates, variables in Fig. 3 were plotted with means of all $\mathrm{N}$ treatments. In 1999, the maximum average NDVI $(n=52)$, determined on 24 August, was 0.67 (range of $0.51-0.82$ ) at the $50 \% \mathrm{ET}$ and 0.73 (range of $0.53-0.87$ ) at the $75 \%$ ET. As shown in Fig. 3a and $3 \mathrm{~b}$, the NDVI increased quickly at the vegetative stage and reached its maximum level before the highest $\mathrm{N}$ uptake (Fig. 3a and 3b) level was measured. Maximum total $\mathrm{N}$ uptake by cotton-including $\mathrm{N}$ in roots, leaves, stems, bolls, and seeds-was 178.2 and $209.5 \mathrm{~kg} \mathrm{ha}^{-1}$ in 1998 and 168.1 and $185.3 \mathrm{~kg} \mathrm{ha}^{-1}$ in 1999 at the 50 and $75 \%$ ET, respectively. Typically, total $\mathrm{N}$ uptake, measured in 1999 , varied from 3.2 to $17.3 \mathrm{~kg} \mathrm{ha}^{-1}$ in early July (Fig. 3a and 3b). From bloom (beginning of July) to open boll (end of August), total $\mathrm{N}$ uptake increased exponentially from 24.4 to $120.6 \mathrm{~kg} \mathrm{ha}^{-1}$ and from 35.0 to $132.3 \mathrm{~kg} \mathrm{ha}^{-1}$ at the 50 and $75 \%$ ET irrigation levels, respectively. The $\mathrm{N}$ uptake reached a maximum in early September and then declined at the beginning of plant defoliation (Fig. $3 \mathrm{a}$ and $3 \mathrm{~b}$ ).

Cotton PWC and plant fresh biomass (PFB) development showed an S-shaped pattern, as demonstrated by the measurements taken in 1999 (Fig. 3c and 3d). Maximum PFB was 30.6 and $34.7 \mathrm{Mg} \mathrm{ha}^{-1}$ in 1998 and 31.2 and $35.3 \mathrm{Mg} \mathrm{ha}^{-1}$ in 1999 at the 50 and $75 \% \mathrm{ET}$, respectively. Maximum PWC totaled 22.9 and $25.3 \mathrm{Mg} \mathrm{ha}^{-1}$ in 1998 and 23.3 and $26.5 \mathrm{Mg} \mathrm{ha}^{-1}$ in 1999 at the 50 and $75 \%$ ET, respectively. The PWC and PFB values were significantly higher $(P<0.0246)$ at the 75 than the $50 \%$ ET irrigation level. Before bloom (beginning of July), total PWC and PFB were minimal and similar for the two irrigation levels (Fig. 3c and 3d). From bloom (midJuly) to boll maturity (towards mid-September), PFB 

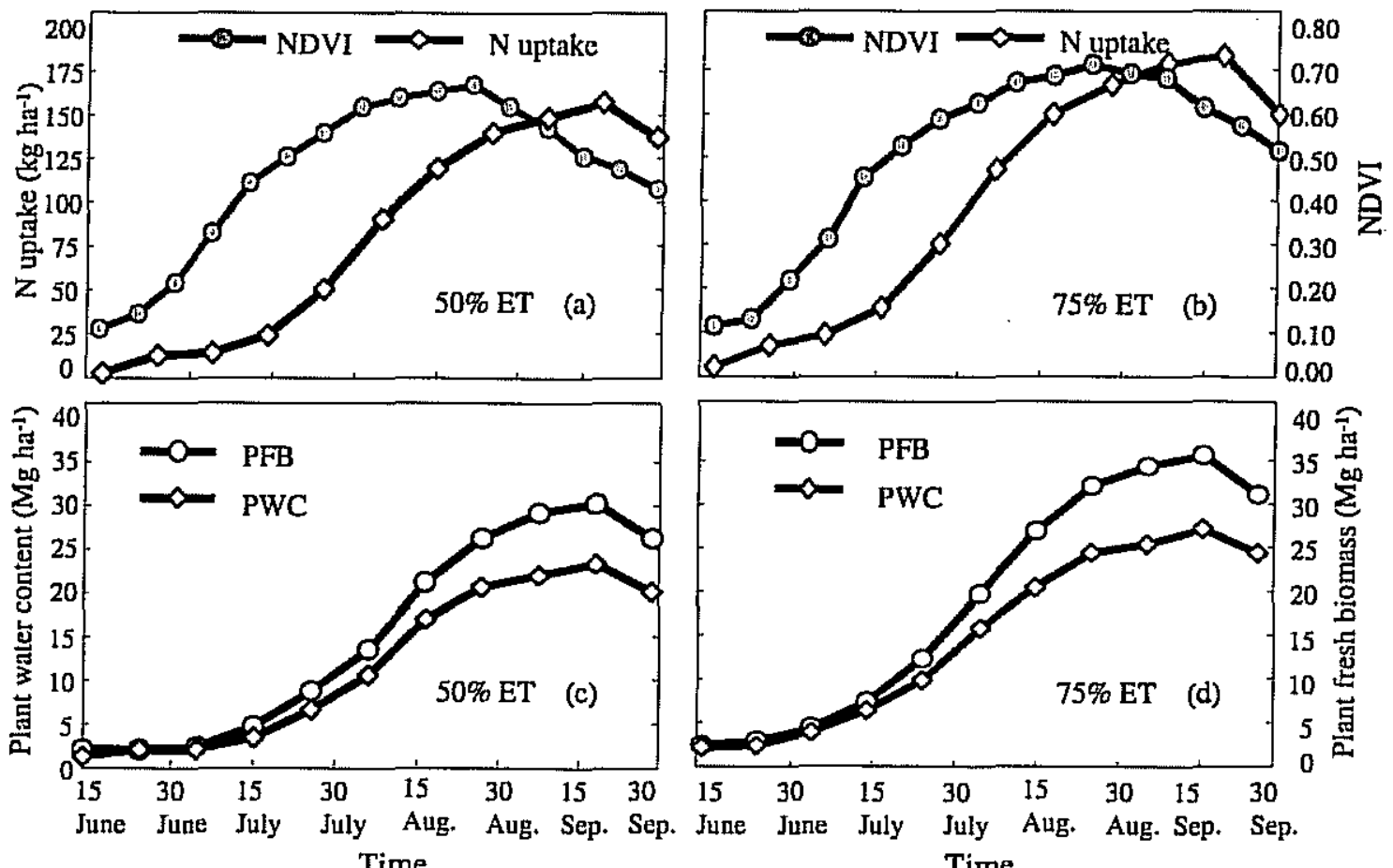

Time

Time

Fig. 3. Temporal patterns of the (a und b) normalized difference vegetative index (NDVI) and $N$ uptake and (c and d) cotton plant water content (PWC) and plunt fresh biomuss (PFB) at the 50 and $75 \%$ evapotranspiration (ET) irrigation levels, measured in $19 y 9$. Data were the mean of $\mathrm{N}$ treatments because $\mathrm{N}$ fertilizer had no effect on these variables.

increased exponentially from 3.59 to $29.1 \mathrm{Mg} \mathrm{ha}^{-1}$ at the $50 \%$ ET and from 3.67 to $34.2 \mathrm{Mg} \mathrm{ha}^{-1}$ at the $75 \%$ ET. The PWC increased from 2.77 to $21.7 \mathrm{Mg} \mathrm{ha}^{-1}$ and from 2.78 to $25.9 \mathrm{Mg} \mathrm{ha}^{-1}$ at the 50 and $75 \%$ ET irrigation levels, respectively. From these peaks, PWC and PFB values declined as cotton bolls opened. Maximum dry matter was 7.91 and $8.75 \mathrm{Mg} \mathrm{ha}^{-1}$, or 25.3 and $24.6 \%$ of the total PFB, for the 50 and $75 \%$ ET irrigation levels, respectively. The PWC and PFB patterns (Fig. $3 \mathrm{c}$ and 3d) showed a similar trend to $\mathrm{N}$ uptake (Fig. $3 \mathrm{a}$ and $3 \mathrm{~b}$ ).

\section{Mixed Effects of Irrigation on Spectral Reflectance}

Mean cotton lint yields were 704 and $962 \mathrm{~kg} \mathrm{ha}^{-1}$ in 1998 and 819 and $924 \mathrm{~kg} \mathrm{ha}^{-1}$ in 1999 at 50 and $75 \%$ ET irrigation levels, respectively. Lint yield varied more in 1998 than 1999; standard deviations were 118 and $186 \mathrm{~kg} \mathrm{ha}^{-1}$ in 1998 compared with 146 and $144 \mathrm{~kg} \mathrm{ha}^{-1}$ in 1999 at 50 and $75 \%$ ET, respectively. The fixed effect of irrigation, determined with a mixed-model procedure, was significant on all measured spectral and agronomic parameters. The fixed effect of $\mathrm{N}$ fertilizer was only significant $(P<0.0281)$ on lint yield in 1999 (Table 1$)$. Interaction between irrigation and $\mathrm{N}$ fertilization was significant only on reflectance in the NIR band $(P<$ 0.0152 ) in 1998 , but the interaction was very significant on red and NIR reflectance as well as NDVI in 1999 (Table 1).

The random effects of the mixed-model variance components (block and treatments) were not significant (Table 2). However, the model residual was significant on all measured spectral and agronomic parameters. The $Z$-statistics for these model variance components are

Table 2. Z-statistics of random variance components (block, and block $\times$ treatments) for variables of red and near infrared (NIR) reflectance, normalized difference vegetative index (NDVI), total $\mathbf{N}$ uptake, and cotton lint yield. Spectral reflectance was measured 17 Aug. 1998 and 24 Aug. 1999 (when maximum NDVI values were determined).

\begin{tabular}{|c|c|c|c|c|c|c|c|c|c|c|}
\hline \multirow[b]{2}{*}{ Sources } & \multicolumn{2}{|c|}{ Red (648-674 nm) } & \multicolumn{2}{|c|}{ NIR $(797-829 \mathrm{~nm})$} & \multicolumn{2}{|c|}{ NDVI } & \multicolumn{2}{|c|}{ N uptake } & \multicolumn{2}{|c|}{ Lint yield } \\
\hline & $\mathbf{Z}$ & $\boldsymbol{P}$ & $z$ & $\boldsymbol{P}$ & $z$ & $\boldsymbol{P}$ & $Z$ & $\boldsymbol{P}$ & $\mathbf{Z}$ & $P$ \\
\hline \multicolumn{11}{|c|}{1998} \\
\hline \multicolumn{11}{|c|}{$\underline{1999}$} \\
\hline
\end{tabular}




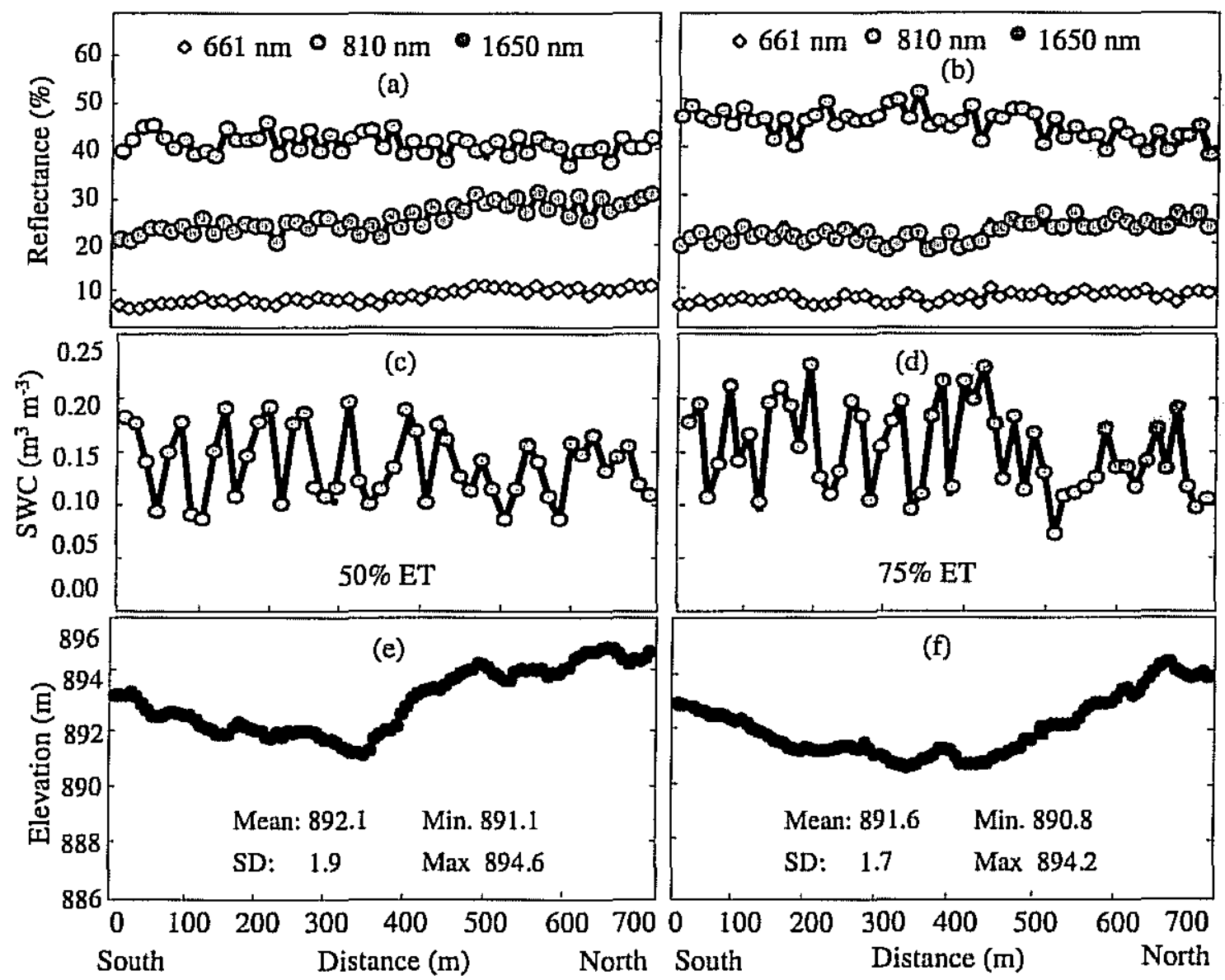

Fig. 4. Spatisl pattern of (a and b) soil and cotton reflectance at center 661, 810, and 1650 nm related to (c and d) soil water content (SwC) and (e and f) site elevation (SE) at the 50 and $75 \%$ evupotranspiration (ET) irrigation level. Datu were measured across all plots in midAugust 1999.

based on asymptotic normality. Except for the $\mathrm{N}$ uptake in 1999 , all $Z$-statistics values varied between 6.36 and 6.56 , with $P=0.0001$ (Table 2). The model residual effects consisted of the covariance of other independent variables such as SE, slope length, and soil texture.

\section{Spatial Patterns of Reflectance Related to Elevation and Soil Water and Texture}

The spectral reflectance in the visible red, NIR, and MIR band varied with irrigation level, SWC, soil texture, and SE. In mid-August 1998, when the seasonal maximum NDVI was determined, the average (all plots, $n=52$ per ET) red, NIR, and MIR reflectance was 7.2, 45.9 , and $23.7 \%$, respectively, on the $75 \%$ ET plots compared with $10.3,42.0$, and $30.1 \%$, respectively, on the $50 \%$ ET plots. As a result, differences in NIR reflectance $(797-829 \mathrm{~nm})$ and red reflectance $(648-674 \mathrm{~nm})$ were significant (Table 1).

Variations of spectral reflectance with SWC and SE are shown in Fig. 4 when the spectral and SWC measurements were taken across all plots at plant maturity in mid-August 1999. The surface SWC (0-0.06 m), which would influence spectral soil and cotton plant reflectance, ranged between 0.060 and $0.273 \mathrm{~m}^{3} \mathrm{~m}^{-3}$ (Fig. $4 \mathrm{a}$ and 4d). The NIR reflectance (center $810 \mathrm{~nm}$ ) was significantly higher (Table 1) on $75 \%$ ET plots $(44.5 \%)$ than on $50 \%$ ET plots $(41.9 \%)$. Correspondingly, the narrow red reflectance (center $661 \mathrm{~nm}$ ) was significantly lower (Table 1) on the $75 \%$ ET $(6.8 \%)$ than the $50 \%$ ET plots $(8.3 \%)$. Compared with the $75 \%$ ET, the MIR reflectance (center $1650 \mathrm{~nm}$ ) was higher at the $50 \% \mathrm{ET}$ ( 24.9 vs. $22.1 \%$ ). From south to north across the field, the consistent trend was that the NIR reflectance was higher ( $48 \mathrm{vs.} 41 \%$ ) on lower positions than on upslopes while red and MIR reflectance increased (6.8 to $10.6 \%$ and 22.3 to $30.8 \%$, respectively) towards the northern upslope areas (Fig. 4a and 4b). Spectral soil and cotton plant characteristics seem to be linked to irrigation level and $\mathrm{SE}$ variability.

Soils in depression areas (middle field) were found to contain more sand on the surface than on northern upslope areas, which also modified the spatial pattern of reflectance in red, NIR, and MIR bands across the field. Sand content (in $0-0.3 \mathrm{~m}$ soil) was higher (740$828 \mathrm{~g} \mathrm{~kg}^{-1}$ ) on depressions (center field) where the NIR reflectance increased but red and MIR reflectance decreased (Fig. 4). The NIR reflectance decreased from 50 to $44 \%$, but red and MIR reflectance increased from 8 to $11 \%$ and from 22 to $28 \%$, respectively, towards the 
Table 3. Linear correlation ( $r$ ) between site elevation (SE); soil texture; soil and cotton surface temperature; reflectance in the visible, near infrared (NIR), and midinfrared (MIR) bands; normalized difference vegetative index (NDVI); and NIR/red ratio (mensured on all plots on 17 Aug. 1998).

\begin{tabular}{|c|c|c|c|c|c|c|c|c|}
\hline Variables & Temperature & Blue & Green & Red & NIR & MIR & NDVI & NIR/Red \\
\hline $\begin{array}{l}\text { Elevation } \\
\text { Sand } \\
\text { Clay }\end{array}$ & $\begin{array}{r}0.73^{* *} \\
-0.50^{* *} \\
0.44^{* *}\end{array}$ & $\begin{array}{c}0.74^{* *} \\
-0.34^{*} \\
0.37^{* *}\end{array}$ & $\begin{array}{c}0.79^{* *} \\
-0.29 \text { nst } \\
0.31^{*}\end{array}$ & $\begin{array}{r}\text { earson } \\
0.80^{* *} \\
-0.41^{* *} \\
0.36^{* *}\end{array}$ & $\begin{array}{c}-0.49^{* *} \\
0.32^{*} \\
-0.06 \mathrm{~ns}\end{array}$ & $\begin{array}{r}0.83^{* *} \\
-0.36^{* *} \\
0.35^{* *}\end{array}$ & $\begin{array}{r}-0.68^{* *} \\
0.42^{* *} \\
-0.34^{*}\end{array}$ & $\begin{array}{r}-0.79 * * \\
0.36^{* *} \\
-0.29 \mathrm{~ns}\end{array}$ \\
\hline
\end{tabular}

* Significant at the 0.05 level.

** Significant at the 0.01 level.

$\dagger$ ns, nonsignificant.

northern upslope area where sand content was lower (620-790 $\left.\mathrm{g} \mathrm{kg}^{-1}\right)$. As a result, the NDVI showed a close dependence on sand content. At plant maturity in August, the higher NDVI values (0.6-0.8) were measured on depressions in the center of the field, and the NDVI was lower on the northern upslope areas where soils contained more clay (194-274 $\mathrm{g} \mathrm{kg}^{-1}$ ) but less sand than in other parts across the plots (data not shown).

\section{Correlation of Cotton Spectral and Agronomic Variables and Field Heterogeneity}

Spectral reflectance in the blue, green, red, and MIR bands was positively correlated with SE and clay content, but the NIR reflectance, NDVI, and NIR/red ratio had a negative correlation relationship with these two field-heterogeneity variables (Table 3). The SE and sand content were also closely linked to SWC, cotton lint yield, and total $\mathrm{N}$ uptake (2-yr mean). The negative or positive correlation coefficient $(r)$ indicated that higher lint yield and $\mathrm{N}$ uptake and more SWC accumulation were associated with low elevation and high sand content (Table 4). The reflectance in the visible, NIR, and MIR bands was highly correlated with each other $(-0.67<r<0.98)$. There was a negative correlation of blue, green, red, and MIR reflectance with lint yield, $N$ uptake, and SWC. Red and MIR reflectance was also negatively correlated with PWC (Table 4). Conversely, the NIR reflectance, NDVI, and NIR/red ratio were positively correlated with these parameters (Table 4).
The reflectance in the NIR band $(797-829 \mathrm{~nm})$ was exponentially related to PFB $\left(R^{2}=0.93\right.$; Fig. 5a), illustrated with data measured on $75 \%$ ET plots in 1998 . The reflected NIR energy increased more quickly with an increase of PFB at early vegetation than late in the season (Fig. 5a). The NIR reflectance was near $50 \%$ of the total reflected radiance when the $\mathrm{PFB}$ ranged between 2500 and $2800 \mathrm{~g} \mathrm{~m}^{-2}$ (Fig. 5a). The reflectance in the MIR band (1523-1752 nm) was exponentially sensitive $\left(R^{2}=0.90\right)$ to PWC in 1998 (Fig. 5b). The MIR reflectance was lower with higher PWC. The MIR reached the lowest level $(22-25 \%$ of the total reflected radiance) when plants contained 1800 to $2000 \mathrm{~g} \mathrm{~m}^{-2}$ water (Fig. 5b).

The SE explained the largest portion (60-62\%) of red and NIR reflectance variation (Fig. 6). The monthly mean red reflectance increased (Fig. 6a) while NIR reflectance decreased significantly (Fig. 6b) with increasing SE. The spatial distribution of the NDVI was heterogeneous. As shown in Fig. 7, the NDVI values determined in midAugust were also heterogeneously distributed in the area with the same irrigation and $\mathrm{N}$ fertilization level. As a result of significant interaction between irrigation and $\mathrm{N}$ fertilizer on NIR reflectance (Table 1), NDVI was higher in the $90 \mathrm{~kg} \mathrm{~N} \mathrm{ha}^{-1}$ plot (Fig. 7a) than in the $135 \mathrm{~kg} \mathrm{~N} \mathrm{ha}^{-1}$ plot (Fig. 7b). The $75 \%$ ET plots had higher NDVI values ( $\geq 0.74)$ with higher frequency $(\geq 15 \%$ ) compared with the $50 \%$ ET plots. The heterogeneous distribution of the NDVI in the area with the

Table 4. Linear correlation coefficient $(r)$ between site elevation (SE), sand, reflectance, cotton lint yield, soil water content (SWC), plant water content (PWC), lenf $\mathrm{N}$, $\mathrm{N}$ uptake and plant fresh biomass (PFB), normalized difference vegetative index (NDVI), and near infrared (NIR)/red reflectance ratio.

\begin{tabular}{|c|c|c|c|c|c|c|}
\hline Variables & Lint yicld & swC $\dagger$ & PWC & Leaf $N+$ & N uptake $\ddagger$ & PFB $\div$ \\
\hline & \multicolumn{6}{|c|}{ Pearson coefficient, $r+$} \\
\hline $\begin{array}{l}\text { Topography und soil } \\
\text { Elevation } \\
\text { Sand }\end{array}$ & $\begin{array}{r}-0.73^{* *} \\
0.54^{* \neq}\end{array}$ & $\begin{array}{c}-0.55^{\neq *} \\
0.34^{*}\end{array}$ & $\underset{0.39 *}{-0.35 \mathrm{~ns}}$ & 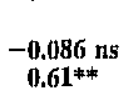 & $\begin{array}{c}-0.62^{* *} \\
0.43^{*}\end{array}$ & $\begin{array}{c}-0.58^{* * *} \\
0.46^{*}\end{array}$ \\
\hline Reflectance $\dagger$ & & & & & & \\
\hline $\begin{array}{l}\text { Blue }(447-474 \mathrm{~nm}) \\
\text { Green }(546-571 \mathrm{~nm}) \\
\text { Red }(648-674 \mathrm{~nm}) \\
\text { NIR }(797-829 \mathrm{~nm}) \\
\text { MIR }(1523-1752 \mathrm{~nm})\end{array}$ & $\begin{array}{c}-0.80^{* *} \\
-0.87^{* *} \\
-0.83^{* *} \\
0.40^{*} \\
-0.86^{* *}\end{array}$ & $\begin{array}{c}-0.63^{* *} \\
-0.70^{* * *} \\
-0.70^{* * *} \\
0.43^{*} \\
-0.67^{* *}\end{array}$ & $\begin{array}{c}-0.28 \mathrm{~ns} \\
-0.32 \mathrm{~ns} \\
-0.40^{*} \\
0.09 \mathrm{~ns} \\
-0.41^{*}\end{array}$ & $\begin{array}{l}-0.31 * \\
-0.35 \mathrm{~ns} \\
-0.24 \mathrm{~ns} \\
-0.02 \mathrm{~ns} \\
-0.24 \mathrm{~ns}\end{array}$ & $\begin{array}{c}-0.63^{* *} \\
-0.76^{* *} \\
-0.72^{* * *} \\
0.49^{*} \\
-0.75^{* *}\end{array}$ & $\begin{array}{r}-0.67^{* * *} \\
-0.62^{* * *} \\
-0.58^{* *} \\
0.52^{* *} \\
-0.54^{* *}\end{array}$ \\
\hline \multicolumn{7}{|l|}{ Spectral index } \\
\hline $\begin{array}{l}\text { NDVI } \\
\text { NIR/Red }\end{array}$ & $\begin{array}{l}0.80^{* * *} \\
0.79 * *\end{array}$ & $\begin{array}{l}0.69 * * \\
0.68^{* * *}\end{array}$ & $\begin{array}{l}0.45^{*} \\
0.36 \mathrm{~ns}\end{array}$ & $\begin{array}{l}0.29 \mathrm{~ns} \\
0.20 \mathrm{~ns}\end{array}$ & $\begin{array}{l}0.84^{* *} \\
0.81^{* *}\end{array}$ & $\begin{array}{l}0.81^{* * *} \\
0.73^{* * *}\end{array}$ \\
\hline
\end{tabular}

* Significant at the 0.05 level.

** Stgnificant at the 0.01 level.

$\dagger$ Reflectance and SWC were measured on 20 and 1 August.

$\ddagger$ PWC, leaf N, and $\mathbf{N}$ uptake were measured on 15 Sept. $19 y 8$.

$\$ \mathrm{~ns}$, nonsignificant. 

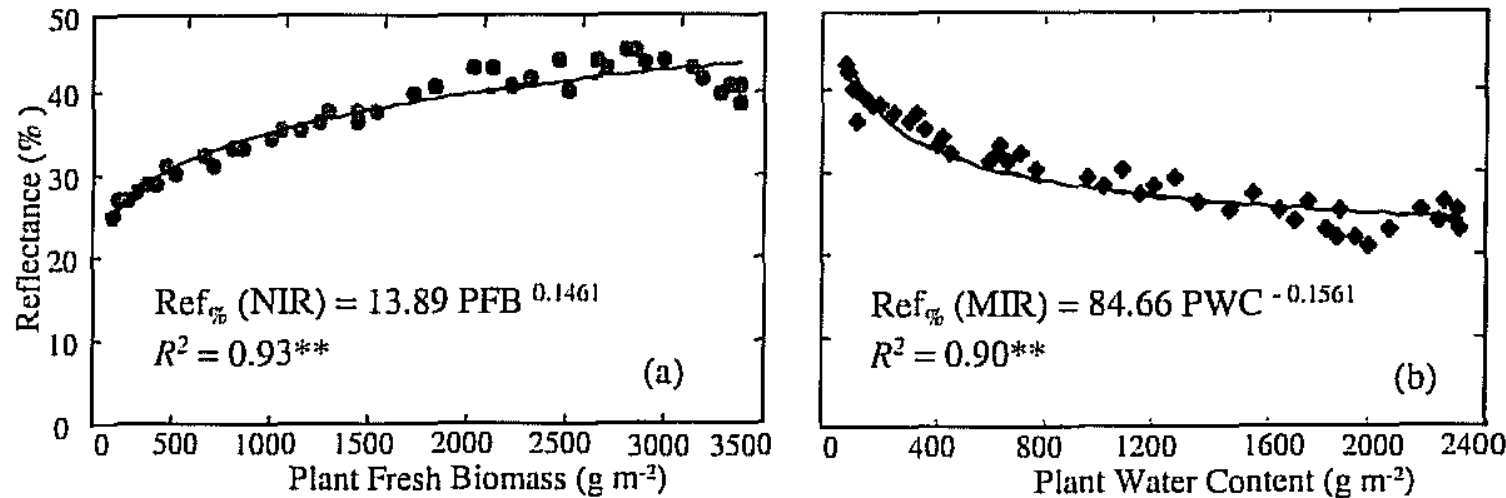

Fig. 5. Relation between (a) reflectance in the near infrared (NIR) band (797-829 nm) and plant fresh biomass (PFB) and (b) reflectance in the midinfrared (MIR) band (1523-1752 $\mathrm{nm}$ ) and cotton plant water content (PWC). Mean of all plots measured in 1998. ** Significant at the 0.01 level.

same irrigation and $\mathrm{N}$ fertilization level reflected the impact of SE and soil texture on soil water distribution, $\mathrm{N}$ uptake, and plant growth.

\section{Cross Correlation Distance between Variables}

There was a positive and/or negative feedback relationship between NIR and red reflectance, NDVI, soil water, clay, sand, and SE (Fig. 8). Their cross correlation covariance $\left[\mathrm{C}_{x y}(\mathbf{h})\right]$, calculated with Eq. [2], ranged between -2.639 and 2.532 along the 50 and $75 \%$ ET plots. As illustrated in the scatter diagram (Fig. 8), the cross correlation functions $\left[\gamma_{x y}(\mathbf{h})\right]$, calculated with Eq. [3], varied between -0.68 and 0.64 . Considering the $95 \%$ confidence level as described by Cassel et al. (2000), the NIR reflectance (Fig. 8a) and NDVI (Fig. 8b) were positively cross-correlated with SWC across a lag distance of $\pm 30 \mathrm{~m}$ (or separation distance of $60 \mathrm{~m}$ ). The NDVI and sand (Fig. 8c) and red reflectance and clay (Fig. 8d) were also positively cross-correlated with each other across a distance between 60 and $75 \mathrm{~m}$. The cross correlation distance between SE and NIR reflectance, NDVI, and red and MIR reflectance varied between 60 and $80 \mathrm{~m}$ (Fig. 8e, 8f, 8g, and $8 \mathrm{~h}$ ). As the lag distance increased, these cross correlation functions positively or negatively approached zero at a lag distance $\geq \pm 180 \mathrm{~m}$ (Fig. 8).

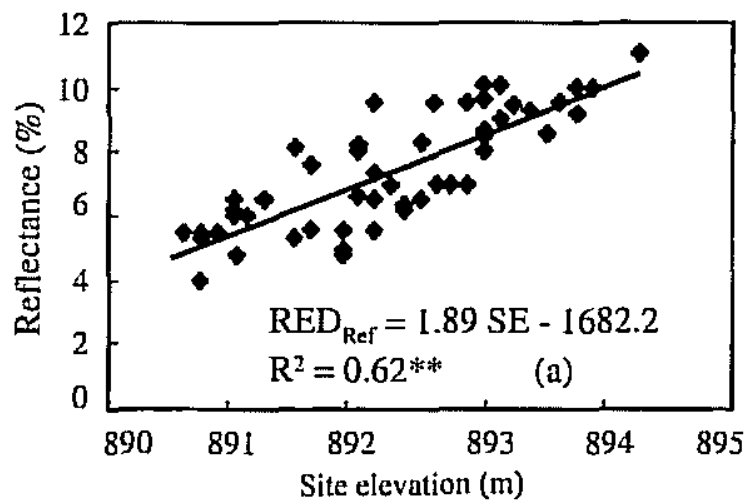

\section{DISCUSSION}

\section{Cotton Spectral Characteristics and Soil and Site Elevation Variability}

The association of the spectral reflectance variability with soil water and texture and SE was spatially cross correlated (Fig. 8), which quantified the spatial correlation structure of the reflectance in red, NIR, and MIR bands across the field. The most significant changes in spectral reflectance associated with SE were an increase of the response in the visible region and a decrease in the NIR reflectance (center $810 \mathrm{~nm}$ ) at higher elevations (Fig. 4). Differences in NIR reflectance can be attributed to differences in canopy density and PFB; red energy is absorbed by leaf chlorophyll, with little transmitted or reflected, and NIR absorption is nearly zero, and reflectance and transmittance are high. There was a great difference in plant density (on average 11 vs. 7.5 plant $\mathrm{m}^{-2}$ ) and PFB (on average 32.5 vs. $23.5 \mathrm{Mg} \mathrm{ha}^{-1}$ ) between lower and higher elevations across the field. The plant density, measured at the vegetative and bloom growth stage at each plot, was higher $\left(10-12\right.$ plant $\left.\mathrm{m}^{-2}\right)$ on lower positions in center field areas than on northern upslope areas (6-9 plant $\mathrm{m}^{-2}$ ), and PFB had the same trend, with higher values $\left(30-35 \mathrm{Mg} \mathrm{ha}^{-1}\right)$ on lower areas and lower values (19-28 $\mathrm{Mg} \mathrm{ha}^{-1}$ ) on higher areas. In June 1999, there was evidence of soil erosion with rye-

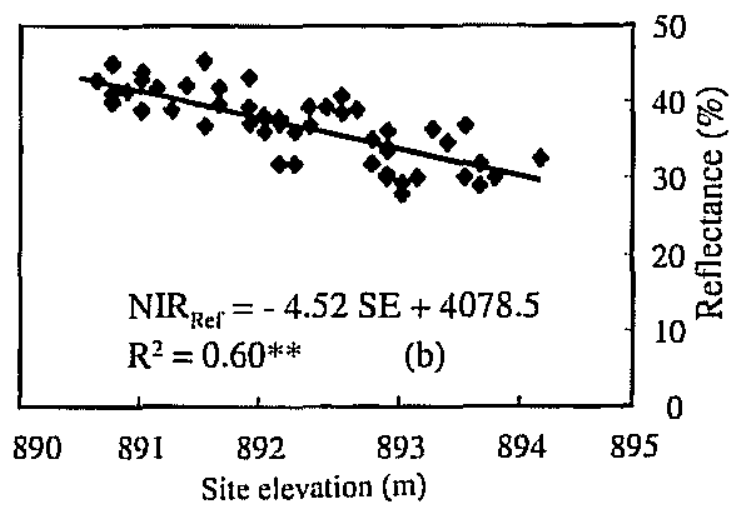

Fig. 6. Regression of (a) red (RED) and (b) near infrared (NIR) reflectance with site elevation (SE). Reflectance data were the monthly mean measured in all plots at 50\% cvapotranspiration (ET) in August 1999. ** Significant at the 0.01 level. 


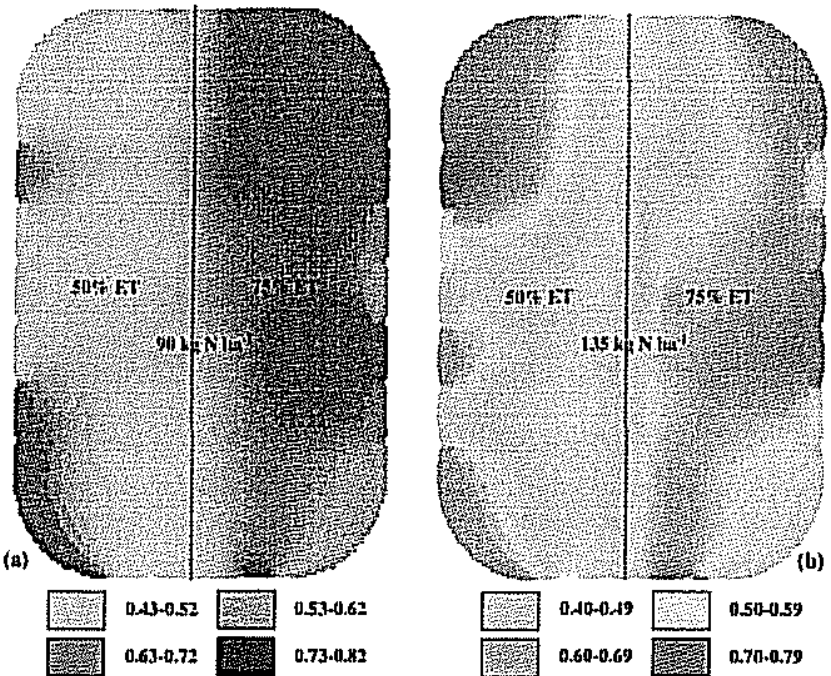

Fig. 7. Normalized difference vegetative index (NDVI) map. Spectrul reflectance data were measured on (a) $90 \mathrm{~kg} \mathrm{~N} \mathrm{hat} \mathrm{plot} \mathrm{and} \mathrm{(b)}$ $135 \mathrm{~kg} \mathrm{~N} \mathrm{ha-1}$ plot on $15 \mathrm{Aug}$. 1998. ET, cvapotrunspiration.

grass (Lolitom sp.) (previous crop) residues and younger plants pulled off from upslope to footslope areas due to the rain. The decline of plant density led to an increase in soil exposure; therefore, red reflectance increased due to soil contribution while NIR reflectance decreased on upslope areas (Fig. 4) where there was less plant coverage. Conversely, red reflectance decreased, but NIR reflectance increased in depressions in the center of the field where plant density and SWC were greater. Asner (1998) also reported that standing litter significantly affected

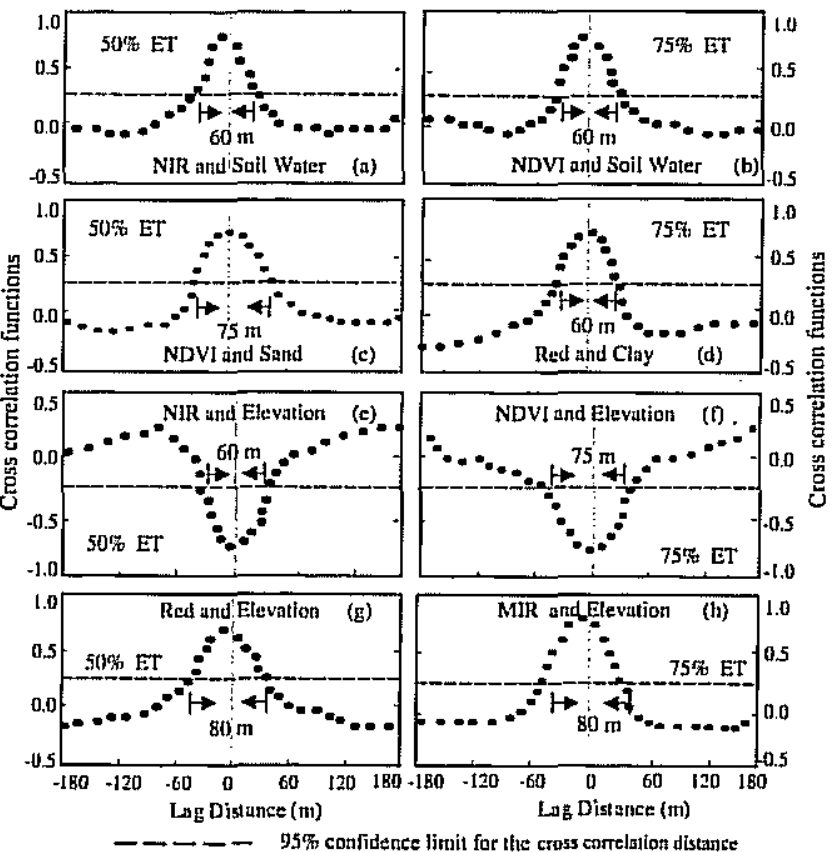

Fig. 8. Cross correlation of (a and b) near infrared (NIR) reflectance and normalized difference vegetative index (NDVI) with soil water content (SWC) in 0 to $0.06 \mathrm{~m}$; (c) NIR reflectance and sand; (d) red reflectance and clay; and (e, f, g, and h) NIR, NDVI, red, and midinfrured (MIR) reflectance with elevation at a ling distance of $\pm 180 \mathrm{~m}$. Soil water content and reflectance data were measured in ull plots on 9 and 24 Aug. 1999, respectively. ET, evapotranspiration. the reflectance characteristics of grassland canopies. Our results demonstrated that small increases in SE had a large effect on cotton canopy reflectance as indicated by the $R^{2}$ values (Fig. 6).

Sand content appears to have more impact on spectral reflectance, soil water, and lint yield than does clay (Table 4). Surface soils $(0-0.3 \mathrm{~m}$ ) in depressed areas contained on average $10 \%$ more sand than on northern upslope and summit where soils had $8 \%$ more clay (127$234 \mathrm{~g} \mathrm{~kg}^{-1}$ ) than on depressed areas (116-210 $\left.\mathrm{g} \mathrm{kg}^{-1}\right)$. Sand has accumulated in the surface layer in depressed areas where the surface soil dried, but the subsoil contained more water (Fig. 4) where there was a higher plant density. As a result, NIR increased in depressed areas where surface soil contained more sand and less clay, which led to a negative correlation between visible reflectance and sand and SE (Table 3). Because higher sand content was found on downslope areas where NIR reflectance increased, correlations between sand and visible reflectance were negative (Table 3 ).

Increasing SWC resulted in an increase of PWC, PFB, $\mathrm{N}$ uptake (Table 4), and NIR reflectance but a decrease of reflectance in the visible and MIR bands (Fig. 4). Jackson (1984) and Bowman (1989) reported that NIR and MIR reflectance varied primarily as a function of leaf water content. Reflectance in the NIR band is determined by plant cell structure and chlorophyll and leaf $\mathrm{N}$ content, which were positively correlated (Bausch and Duke, 1996). Our results suggested that a decrease in visible reflectance and an increase in NIR reflectance would indicate a higher water and $\mathrm{N}$ content in plants based on the $r$ values (Table 4).

\section{Treatments and Field Heterogeneity}

The amount of irrigation and interaction between irrigation and $\mathrm{N}$ fertilizer also appeared to significantly affect spectral plant and soil reflectance, $\mathrm{N}$ uptake, and lint yield (Table 1). Soil $\mathrm{NO}_{3}-\mathrm{N}$ amounts could explain the lack of cotton response to $\mathrm{N}$ treatments. In this field, $\mathrm{N}$ fertilizer at a rate of $190 \mathrm{~kg} \mathrm{ha}^{-1} \mathrm{yr}^{-1}$ has been applied to the soil for the last $5 \mathrm{yr}$. The soil $\mathrm{NO}_{3}-\mathrm{N}$ (including residual and fertilizer $\mathrm{N}$ ) in the effective root zone $(0-0.9 \mathrm{~m})$ at bloom was $179 \pm 83 \mathrm{~kg} \mathrm{ha}^{-1}$ at the $50 \%$ ET and $174 \pm 76 \mathrm{~kg} \mathrm{ha}^{-1}$ at the $75 \%$ ET in July 1998 , and the soil $\mathrm{NO}_{3}-\mathrm{N}$ was declined but remained moderately high $\left(103 \pm 30 \mathrm{~kg} \mathrm{ha}^{-1}\right.$ at the $50 \% \mathrm{ET}$ and $120 \pm$ $42 \mathrm{~kg} \mathrm{ha}^{-1}$ at the $75 \%$ ET) in early May (before seeding) 1999. Therefore, larger amounts of soil $\mathrm{NO}_{3}-\mathrm{N}$ was one of the factors causing no effect of $\mathrm{N}$ treatments on the spectral and agronomic parameters in 1998 (Table 1), and the effect of $\mathrm{N}$ rates on lint yield and interaction between the treatments on the red and NIR reflectance and NVDI was significant (Table 1).

Poor rain infiltration and resulting runoff might have influenced cotton response to the treatments. Significant effects of $\mathrm{N}$ fertilizer and interaction between irrigation and $\mathrm{N}$ fertilizer on lint yield could be expected in a wet year such as in 1999 (Table 1). The 1998 growing season was exceptionally dry (total rain was $22 \%$ of the $30-\mathrm{yr}$ average), but the 1999 season was unusually wet in June (190\% of the $30-y r$ average). The SWC in the rooting 
depth (0-0.9 m) in June was on average $0.14 \mathrm{~m}^{3} \mathrm{~m}^{-3}$ in 1999 compared with $0.09 \mathrm{~m}^{3} \mathrm{~m}^{-3}$ in 1998 . As a result, the lint yield with $50 \%$ ET increased $14 \%$ in 1999 compared with 1998. Soil water and N supply were strongly linked to cotton production (Wiegand et al., 1994; Plant et al., 2000; Li et al., 2001a), and annual rain difference contributed to grass NDVI variability (Paruelo and Lauenroth, 1998).

Changes in cotton spectral characteristics, soil water, $\mathrm{N}$ uptake, and lint yield were largely controlled by SE rather than by soil texture and $\mathrm{NO}_{3}-\mathrm{N}$. The significance of the mixed-model residual (Table 2) indicated the degree of influence of covariables such as SE, slope length, and sand and clay content on cotton spectral characteristics, soil water, $\mathrm{N}$ uptake, and lint yield. Our results suggested that real-time reflectance in the NIR and red bands and NDVI could represent real-time soil conditions and plant development. An in-season variable water and $\mathrm{N}$ application related to local field heterogeneity would be determined by combining a NDVI map (Fig. 7) with a cross correlation distance (Fig. 8). For example, the amount and locations for $\mathrm{N}$ application can be determined from a real-time NDVI map, and the cross correlation distance between NDVI and SE can be used as a variable rate application distance.

\section{CONCLUSIONS}

Irrigation level, interaction between irrigation and $\mathrm{N}$ fertilizer, and variability in soil water and texture and SE significantly affected agronomic responses of a cotton crop and, thus, the spectral reflectance properties. The NIR reflectance increased significantly with increasing irrigation, SWC, PFB, and plant $\mathrm{N}$ ( $\mathrm{N}$ in leaf, stem, and boll). The most significant relations between spectral and agronomic characteristics were that NIR reflectance varied primarily as a function of PFB and MIR reflectance varied primarily as a function of PWC. Cotton reflectance in visible, NIR, and MIR bands were correlated with SE and sand content along with NDVI, SWC, PWC, N uptake, and lint yield. Cotton lint yield and $N$ uptake were related to the reflectance-based NDVI. Generated NDVI maps showed that the NDVI was heterogeneously distributed in the field. It is concluded that landscape and texture attributes determine the relative contribution of soil, plant, and water factors that drive variation in a reflectance signal. Spectral reflectance data can be used with NDVI mapping to identify real-time spatial patterns of soil water and crop $\mathrm{N}$ by the spatial difference and geoposition of spectral variables. The cross correlation analysis of spectral reflectance, soil texture, and SE could be useful for an inseason adjustment in water and $\mathrm{N}$ fertilizer application. A possible attempt would be to use the cross correlation distance between NDVI and SE as a distance of variable $\mathrm{N}$ application across heterogeneous fields.

\section{ACKNOWLEDGMENTS}

We thank the Idaho National Engineering Laboratory (INEEL) and Texas Agricultural Experiment Station (TAES) for financial support for this project.

\section{REFERENCES}

Ahlrichs, J.S., and M.E. Bauer. 1983. Relation of agtonomic and multispectral reflectance characteristics of spring wheat canopies. Agron. J. 75:987-993.

Asner, G.P. 1998. Biophysical and biochemical sources of variability in canopy reflectance. Remote Sens. Environ. 64:234-253.

Barnes, E.M., M.S. Moran, P.J. Pinter, Jr., and T.R. Clarke. 1997. Multispectral remote sensing and site-specific agriculture: Examples of current technology and future possibilities. p. 803-824. In P.C. Robert et al. (ed.) Precision agriculture. Proc. Int. Conf. Precision Agric., 3rd, Bloomington, MN. 23-26 June 1996. ASA, CSSA, and SSSA, Madison, WI.

Bausch, W.C. 1993. Soil background effects on reflectance-based crop coefficients for corn. Remote Sens. Environ. 46:213-222.

Bausch, W.C., and H.R. Duke. 1996. Remote sensing of plant nitrogen status in corn. Trans. ASAE 39:1869-1875.

Begue, A. 1993. Lear area index, intercepted photosynthetically active radiation, and spectral vegetation indices: A sensitivity analysis for regular-clumped canopies. Remote Sens. Environ. 46:45-59.

Blackmer, T.M., J.S. Schepers, G.E. Varvel, and E.A. Walter-Shea. 1996. Nitrogen deficiency detection of reflectance shortwave radiation from irrigated corn canopies. Agron. J. 88:1-5.

Bowman, W.D. 1989. The relationship between leaf water status, gas exchange, and spectral reflectance in cotton leaves. Remote Sens. Environ. 30:249-255.

Cassel, D.K., O. Wendroth, and D.R. Nielsen. 2000. Assessing spatial variability in an agricultural experiment station field: Opportunities arising from spalial dependence. Agron. J. 92:706-714.

Daughtry, C.S.T., K.P. Goward, S.D. Prince, and W.P. Kustas. 1992. Spectral estimates of absorbed radiation and phytomass production in corn and soybenn canopies. Remote Sens. Environ. 39:141-152.

Gee, G.W., and J.W. Bauder. 1986. Particle-size analysis. p. 383-409. In A. Klute et al. (ed.) Methods of soil analysis. Part 1. 2nd ed. SSSA Book Ser. 5. SSSA, Madison, WI.

Hicks, S.K., and R.J. Lascano. 1995. Estimation of leaf area index for colton canopies using the LI-COR LAI-2000 plant canopy analyzer. Agron. J. 87:458-464.

Jackson, R.D. 1984. Remote sensing of vegetation characteristics for farm management. Remote Sens. 475:81-96.

Jackson, R.D., T.R. Clarke, and M.S. Moran. 1992. Bidirectional calibration results for 11 Spectralon and $16 \mathrm{BaSO}_{4}$ reference reflectance panels. Remote Sens. Environ. 40:231-239.

Jackson, R.D., M.S. Moran, P.N. Slater, and S.F. Biggar. 1987. Field calibration of reference reflectance panels. Remote Sens. Environ. 22:145-158.

Kollenkark, J.C., C.S.T. Daughtry, M.E. Bauer, and T.L. Housley. 1982. Effects of cultural practices on agronomic and reflectance characteristics of soybean canopies. Agron. J. 74:751-758.

Lascano, R.J., R.L. Baumhardt, S.K. Hicks, and J.A. Landivar. 1999. Spatial and temporal distribution of surface water content in a large agricultural field. p. 19-30. In P.C. Robert et al. (ed.) Proc. Int. Conf. Precision Agric., 4th, Minneapolis, MN. 17-20 July 1998. ASA, CSSA, and SSSA, Madison, WI.

Li, H., R.J. Lascano, J. Booker, T.L. Wilson, and K.F. Bronson. $2001 \mathrm{a}$. Cotton lint yield variability in a heterogeneous soil at a landscape scale. Soil Tillage Res. 58:245-258.

Li, H., R.J. Lascano, E. Barnes, J. Booker, L.T. Wilson, E. Segarra, and K.F. Bronson. 2001b. Temporal patterns of cotton reflectance and NDVI-days lint yield modeling. p. 590-594. In P. Dugger and D. Richer (ed.) Proc. Beltwide Cotton Conf., Analıeim, CA. 9-13 Jan. 2001. Natl. Cotton Counc. of Am., Memphis, TN.

Little, R.C., G.A. Milliken, W.W. Stroup, and R.D. Wolfinger. 1996. SAS system for mixed models. SAS Inst., Cary, NC.

Lyle, W.M., and J.P. Bordovsky. 1981. Low energy precision application (LEPA) irrigation system. Trans. ASAE 24:1241-1245.

Maas, S.J. 1998. Estimating cotton canopy ground cover from remotely sensed scene reflectance. Agron. J. 90:384-388.

Pachepsky, Y.A., and J.C. Ritchie. 1998. Seasonal changes in fractal landscape surface roughness estimated from airbone laser altimetry data. Int. J. Remote Sens. 13:2509-2516.

Paruelo, J.M., and W.K. Lauenroth. 1998. Interannual variability of NDVI and its relationship to climate for North American shrublands and grasslands. J. Biogeogr. 25:721-733. 
Plant, R.E., D.S. Munk, B.R. Roberts, R.L. Vargas, D.W. Rains, R.L. Travis, and R.B. Hutmacher. 2000. Relationships between remotely sensed reflectance data and cotton growth and yield. Trans. ASAE 43:535-546.

Richardson, A.J., C.L. Wiegand, D.F. Wanjura, D.F. Dusek, and J.L. Steiner. 1992. Multisite analyses of spectral-biophysical data for sorghum. Remote Sens. Environ. 41:71-82.

SAS Institute. 1990. SAS/STAT user's guide. Vol. 2. GLM-VARCOMP. Version 6. 4th ed. SAS Inst., Cary, NC.

SAS Institute. 1993. SAS/ETS user's guide. Version 6. 2nd ed. SAS Inst., Cary, NC.

Sembiring, H., W.R. Raun, G.V. Johnson, M.L. Stone, J.B. Solie, and S.B. Phillips. 1998. Detection of nitrogen and phosphorus nutrient status in winter wheat using spectral radiance. J. Plant Nutr. 21: $1207-1233$.

Stone, M.L., J.B. Solic, W.R. Raun, R.W. Whitney, S.L. Taylor, and J.D. Ringer. 1996. Use of spectral radiance for correcting in-season fertilizer nitrogen deficiencies in winter wheat. Trans. ASAE 39: 1623-1631.

Technicon Industrial Systems. 1986. Nitrate-nitrite in soil extracts. Industrial method no. 794-86T. Technicon Ind. Syst., Tarrytown, NY.

van Es, H.M., and C.L. van Es. 1993. Spatial nature of randomization and its effects on the outcome of field experiments. Agron. J. 85: 420-428.

van Es, H.M., C.L. van Es, and D.K. Cassel. 1989. Application of regionalized variable theory to large-plot field experiments. Soil Sci. Soc. Am. J. 53:1178-1183.

Walburg, G., M.E. Bauer, C.S.T. Daughtry, and T.L. Housley. 1982. Effects of nitrogen nutrition on the growth, yield, and reflectance characteristics of corn canopies. Agron. J. 74:677-683.

Wiegand, C.L., J.D. Rloades, D.E. Escobar, and J.H. Everitt. 1994. Photographic and videographic observations for determining and mapping the response of cotton to soil salinity. Remote Sens. Environ. 49:212-223.

\title{
NOTES AND UNIQUE PHENOMENA
}

\section{Separating the Impacts of Crop Diversification and Rotations on Risk}

\author{
Glenn A. Helmers, Charles F. Yamoah, and Gary E. Varvel
}

\begin{abstract}
It has been commonly accepted that crop rotations reduce risk compared with monoculture systems. Quantifying this phenomenon requires tlat effects of yield stability on risk (positive or negative) arising from rotating crops be separated from other risk elements. Using an ARS-University of Nebraska series of yiclds for corn ( $\mathrm{Zea}$ mays L.) and soybeun [Glycine max (L.) Merr.] grown over a 14-yr period, both in rotation and in monoculture, the impact of crop rota" tion on risk was isolated and estimated. Risk was defined as the failure to meet an annual per-liectare net return target. A corn-soybean rotation had significantly less risk than monoculture practices. Diversification was found to contribute to part of this reduction while higher yiclds and reduced cost contributed to the remainder. This reduction in risk occurred even though the corn-soybean rotation bad a higher yield variance.
\end{abstract}

$\mathrm{E}$ XPERIMENTAL YIELD DATA on crops grown under monoculture conditions as well as when sequenced are commonly available from cropping system research studies. Where the experiment is of sufficient duration, the risk consequences of alternative cropping systems can be estimated using yield data along with price and cost data. Further, in doing so, it is often possible to separate the risk effects of crop rotation and crop diversification. The risk benefits of crop diversification are generally well understood, but the additional effect of rotational cropping on risk is less understood. Further, it is important to understand the underlying causes when rotations reduce risk.

The use of crop rotations have generally been thought to reduce risk compared with monoculture cropping

G.A. Helmers, Dep. of Agric. Econ., P.O. Box 830922, Univ. of Nebraska, Lincoln, NE 68583-0922; C.F. Yamoah, Soil Res. Inst., Kumasi, Ghana; and G.E. Varvel, USDA-ARS, P.O. Box 830934, Univ. of Nebraska, Lincoln, NE 68583-0934. Journal Ser. no. 13371, Agric. Res. Division, Univ, of Nebraska.

Published in Agron. J. 93:1337-1340 (2001).
(Helmers et al., 1986). The benefit of crop rotations in reducing risk involves three distinct influences. First, conventionally practiced rotations involve diversification, an offsetting phenomenon where low returns in one year for one crop are combined with relatively high returns from a different crop. Second, rotation cropping is generally thought to reduce yield variability compared with monoculture practices. Last, rotations, as opposed to monoculture cropping, may result in overall higher crop yields as well as reduced production costs. Where risk is defined as the failure to reach a target return, these influences may reduce risk by reducing the severity of the return failures.

\section{Cropping System Risk}

Risk is generally considered a strong behavioral force affecting decision making. At the farm level, higher risk may or may not accompany higher profit alternatives. If higher profit alternatives involve less or no greater risk than lower profit alternatives, the higher profit alternative is the obvious choice. When higher profit alternatives involve greater risk, a choice must be made between the two objectives.

Cropping system risk results from variability in returns across time and arises from year-to-year changes in yields, crop prices, and input costs. A number of risk concepts and their analytic implementations exist (Anderson et al., 1977; Harwood et al., 1999). Often variability or a second-moment concept is used in analyzing risk of individual activities or a portfolio of activities (Anderson et al., 1977; Freund, 1956). The portfolio analysis approach based on the foundation of utility maximization has also been linearized (Hazell, 1971). Another perspective of risk is how far and/or often returns fail to reach a below-mean target return level (Held et al., unpublished, 1982; available from the corresponding author) (Tauer, 1983; Watts et al., 1984). In 